\title{
Gladiador
}

Recebido em 29-10-2019 Aceito para publicação em 27-01-2020

\section{doi https://doi.org/10.47456/simbitica.v7i3.33712}

\section{Maurício de Novais Reis}

ORCID: 0000-0003-4154-4242

Graduado em Pedagogia e em Filosofia, especialista em Teoria Psicanalítica e mestre em Ensino e Relações Étnico-Raciais (UFSB). Leciona Filosofia na rede estadual da Bahia e possui quatro livros publicados, além de poemas, contos e artigos acadêmicos publicados em antologias literárias e periódicos científicos. E-mail: contato@mauricionovais.com

Não sou nada

Senão um gladiador

Insano

Lutando contra leões

No Coliseu romano

Ou um guerreiro negro

Africano

Na luta diária contra a colonização

De peito aberto

Sangrando

$\mathrm{O}$ banzo incontido

Da escravidão.

Não sou nada

Senão um caçador

Pré-histórico

Entesando o arco

\section{Heroico}

Ou um lutador hebreu

Arcaico

Cercado de pentateucos

Laicos 
Protótipo estoico

O espírito aflito

$\mathrm{Na}$ tradição.

Não sou nada

Senão um poeta

Balzaquiano

Traço incontido do desejo

Humano

Na divina comédia

Ou um prosaico suburbano

Lutando como um guerreiro

Insano

Essa batalha dantesca.

Não posso ser nada

Senão a carne que regenera

Com o tempo

Senão o musicista que demarca

$\mathrm{O}$ andamento

Do mundo através de palavras.

Não posso ser nada

Senão a incerteza do eco

Desses gritos perplexos

Ante a humanidade

Desumana.

Não posso ser nada

Senão a incontestável solidão

De humano, demasiado

Humano

Num planeta deserto de intelecto

Bélico

E alegadamente

Plano. 